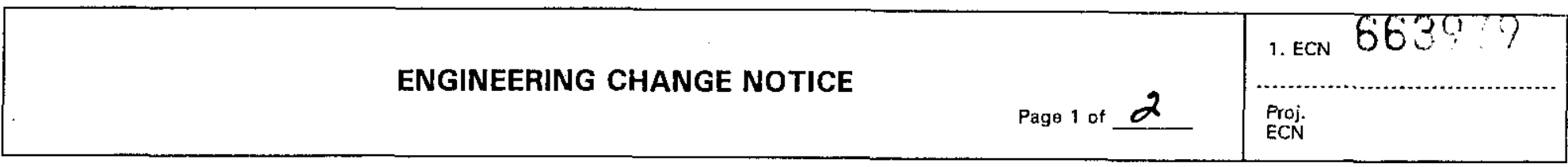

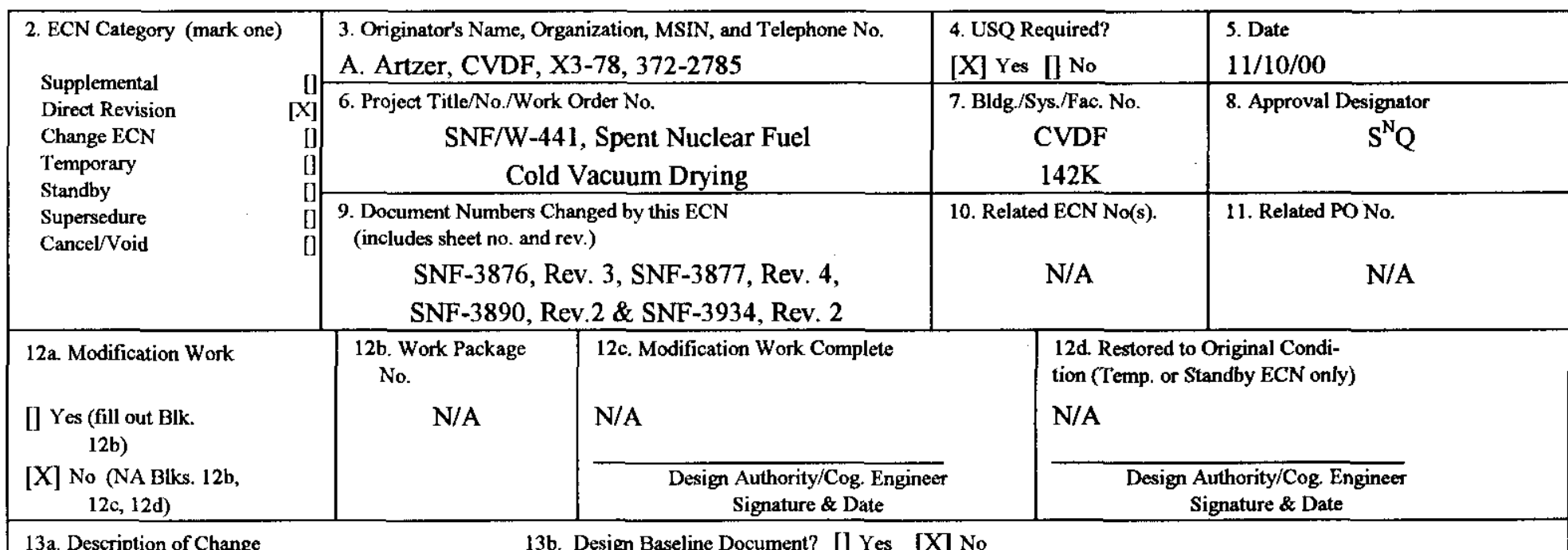

HOOD

Added note that either actuator Model Number is acceptable; revised valve failure position sampling size to $100 \%$; Revised stroke time to be a separate item in Section 4, By Special Test and Section 5.

USQ Approval:

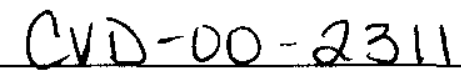

$\begin{array}{ll}\text { 14a. Justification (mark one) } \\ \text { Criteria Change } & \text { [] } \\ \text { Design Improvement } & \text { [] } \\ \text { Environmental } & {[]} \\ \text { Facility Deactivation } & \text { [] } \\ \text { As-Found } & \text { [X] } \\ \text { Facilitate Const } & \text { [] } \\ \text { Const. Error/Omission } & \text { [] } \\ \text { Design Error/Omission } & \text { [] }\end{array}$

15. Distribution (include name, MSIN, and no. of copies)

See distribution sheet.

14b. Justification Details

The CGI dedication document is being revised to rely on physical verification of valve failure position instead of relying on inspection of part number to verify valve failure position.

The design verification method for SC/SS components is by independent review in accordance with EN-6-027-01. Documentation of this review is accomplished by the independent review approval signature provided on page 2 of this ECN. 


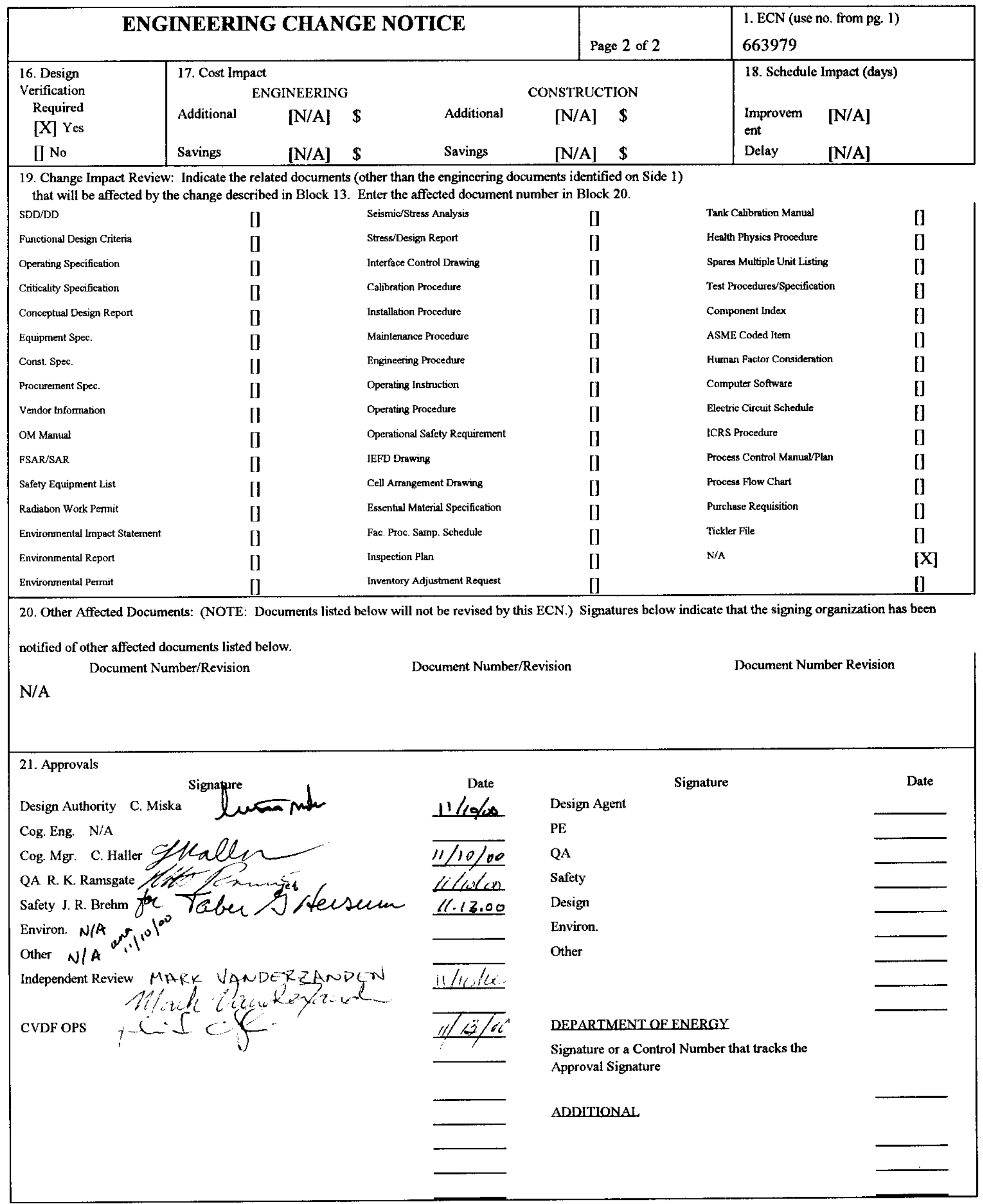


DISTRIBUTION SHEET

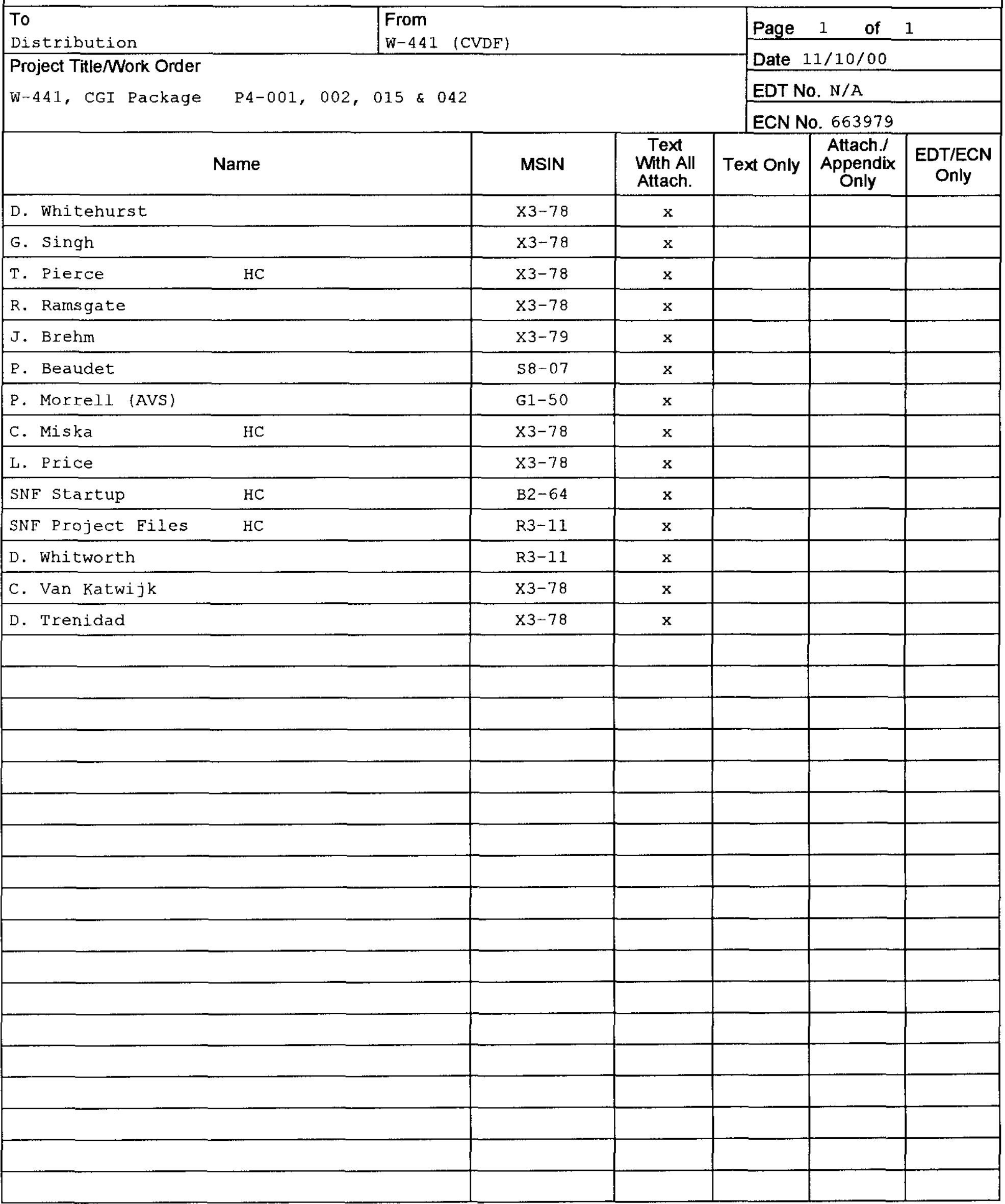


SNF-3890

Revision 3

\section{Worcester Solenoid- Actuated Gas-Operated MCO Isolation Valves}

Prepared for the U.S. Department of Energy

Assistant Secretary for Environmental Management

Project Hanford Management Contractor for the

U.S. Department of Energy under Contract DE-AC06-96RL13200

Fluor Hanford

P.O. Box 1000

Richland, Washington 
SNF-3890

Revision 3

ECN 663979

\section{Worcester Solenoid-Actuated Gas- Operated MCO Isolation Valves}

Project No: W-441

Division: SNF

C. R. Miska

Fluor Hanford, Inc.

Date Published

November 2000

Prepared for the U.S. Department of Energy

Assistant Secretary for Environmental Management

Project Hanford Management Contractor for the

U.S. Department of Energy under Contract DE-AC06-96RL13200

\section{Fluor Hanford}

P.O. Box 1000

Richland, Washington
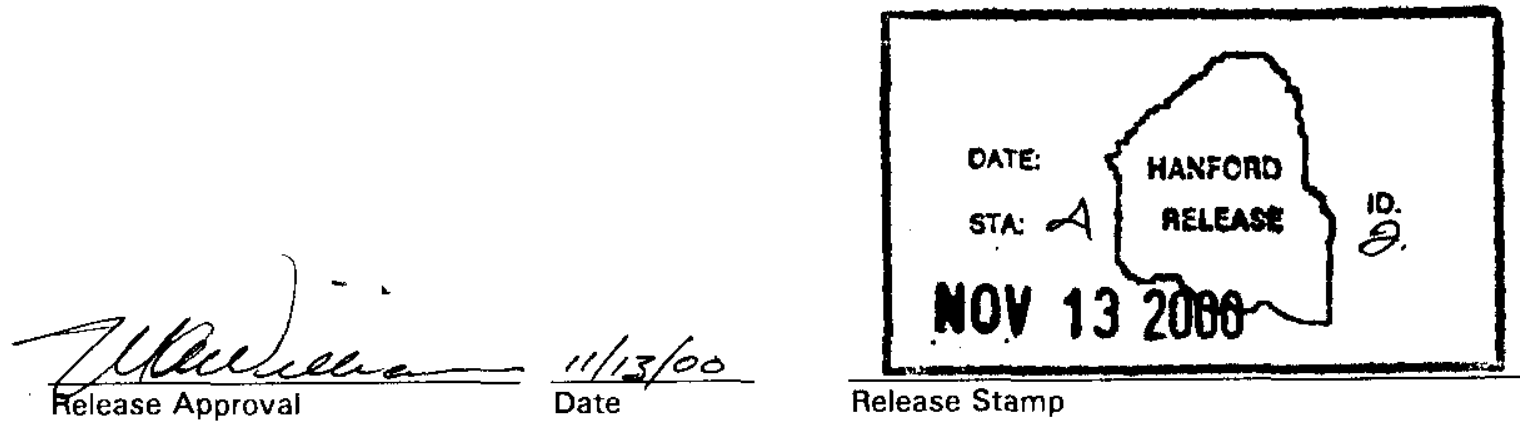


\section{TRADEMARK DISCLAIMER}

Reference herein to any specific commercial product, process, or service by trade name, trademark, manufacturer, or otherwise, does not necessarily constitute or imply its endorsement, recommendation, or favoring by the United States Government or any agency thereof or its contractors or subcontractors.

This report has been reproduced from the best available copy.

Printed in the United States of America

Total Pages: $\quad 1 / 4$

SNF. 3890, 2003 
RECORD OF REVISION

(2) Title

WORCESTER SOLENOID-ACTUATED GAS-OPERATED MCO ISOLATION VALVES

Change Control Record

(3) Revision

(7)

1

RS
(4) Description of Change - Replace, Add, and Delete Pages

(7)

EDT 626263, INITIAL RELEASE

ECN 653776, REVISION TO MEET REV. 6 OF SEL

ECN 660518, REVISION TO MEET INTERNAL PRESSURE ACCEPTANCE CRITERIA

ECN 663979, REVISED VALVE FAILURE POSITION

SAMPLING SIZE AND STROKE TIME
Authorized for Release

\begin{tabular}{|c|c|c|}
\hline (5) Cog. Engr. & (6) Cog. Mgr. & Date \\
\hline IRWIN & $\mathrm{CHOHO}$ & \\
\hline VAN KATWIJK & MISKA & \\
\hline VAN KATWIJK & $\mathrm{CHOHO}$ & \\
\hline & $c$ & \\
\hline
\end{tabular}

Page 1 


\begin{tabular}{|l|l|}
\hline Commercial Grade Item Upgrade Dedication Form & SNF-3890, Rev. 3 \\
\hline $\begin{array}{l}\text { ECN No. NA CGI No. CGI-SNF-D-46-1-P4-015 } \\
\text { Titte: Worcester Solenoid-Actuated Gas-Operated MCO Isolation Valves }\end{array}$ & Page 1 of 10 \\
\hline
\end{tabular}

\begin{tabular}{|c|c|c|c|c|}
\hline \multicolumn{5}{|c|}{ 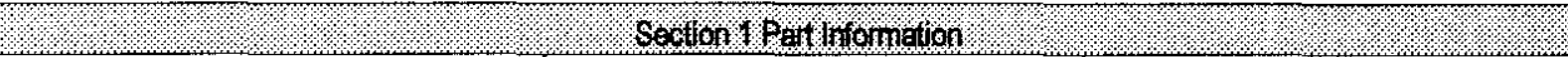 } \\
\hline \multicolumn{2}{|c|}{ Item No.: N/A } & Manufacturer: N/A & & N/A \\
\hline \multicolumn{3}{|c|}{ Mfg. PartModel No.: NA } & \multicolumn{2}{|l|}{ Supplier's PN: N/A } \\
\hline \multicolumn{5}{|c|}{ Part Description: N/A } \\
\hline \multicolumn{5}{|c|}{ End Use Description: NA } \\
\hline \multicolumn{5}{|c|}{ Section 2 a congonght Intomation: } \\
\hline \multicolumn{2}{|c|}{$\begin{array}{l}\text { Equipment No.: PWC- } \\
\text { GOV/SOV-1*03 \& 1*30 }\end{array}$} & $\begin{array}{l}\text { Specification No:: } \\
\text { SNF-5303 } \\
\text { (W-441-P4) }\end{array}$ & $\begin{array}{l}\text { Manufacturer: } \\
\text { Worcester Controls }\end{array}$ & Past P.O. No.: N/A \\
\hline \multicolumn{2}{|c|}{$\begin{array}{l}\text { Procurement and/or Model } \\
\text { Number: } \\
\text { 1" E 5966RTBW4 with } \\
\text { 151939SWM2120PBC }\end{array}$} & \multicolumn{2}{|c|}{$\begin{array}{l}\text { Equipment Supplier (if different from manufacturer): } \\
\text { Olympic Tool \& Engineering }\end{array}$} & $\begin{array}{l}\text { Equip. Supplier's Part No: } \\
\text { N/A }\end{array}$ \\
\hline \multicolumn{5}{|c|}{$\begin{array}{l}\text { Component Description: These valves are 1" gas-operated full-port ball valves incorporating a solenoid and limit } \\
\text { switches as integral parts of the actuator that are used in process streams within the CVDF hood. The valves fail } \\
\text { closed (on loss of pressure or electrical) to prevent MCO vent drain to either reduce air in-leakage or loss of He. The } \\
\text { valves have couplings for transverse actuator mounting. }\end{array}$} \\
\hline \multicolumn{5}{|c|}{ 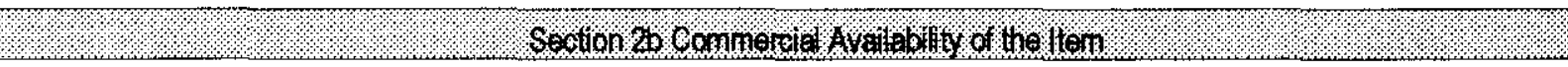 } \\
\hline \multicolumn{5}{|c|}{$\begin{array}{l}\text { 1. Is the Item available from a catalogue from a qualified NQA1 supplier or ISO } 9000 \text { supplier (coordinate with project CGI } \\
\text { interface Engineer or BTR)? }\end{array}$} \\
\hline \multicolumn{4}{|c|}{ [ ] YES (go to \#2 below) } & [X] NO (go to procedure step 6.3.2, proceed to dedicate Item) \\
\hline \multicolumn{5}{|c|}{$\begin{array}{l}\text { If not available from a qualified NQA1 supplier, is it available from an ISO } 9000 \text { supplier? (coordinate w/ project CGI } \\
\text { Interface Engineer or BTR): }\end{array}$} \\
\hline \multicolumn{5}{|c|}{ [ ] Y YES (go to \#2 below, procedure step 6.3.2, dedicate ltem) } \\
\hline \multicolumn{5}{|c|}{ 2. List of Candidate qualified suppliers or ISO 9000 suppliers: N/A } \\
\hline \multicolumn{5}{|c|}{ 3. Recommended Procurement Strategy(coordinate with project CGI interface Engineer or BTR): NA } \\
\hline \multicolumn{5}{|c|}{ 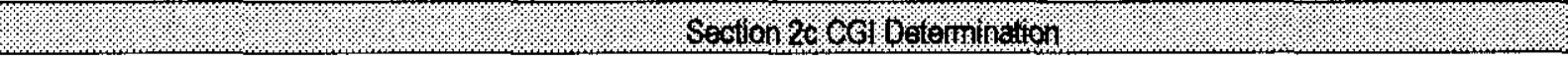 } \\
\hline \multicolumn{5}{|c|}{$\begin{array}{l}\text { CGI Determination Questions: } \\
\text { \#1: Is the ltem subject to design or specification requirements that are unique to nuclear fa } \\
\begin{array}{ll}\text { [ ] YES (the ltem is not commercial grade) } & {[X] N O \text { (continue) }}\end{array}\end{array}$} \\
\hline \multicolumn{5}{|c|}{$\begin{array}{l}\text { [ ] NO (the item is not commercial grade) } \\
\text { \#3: Is the Item ordered from manufacturer/supplier on the basis of specifications set forth in the manufacturer's catalog? } \\
\begin{array}{ll}\text { [ ] NO (the item is not commercial grade) } \\
\text { [X] YES (continue) }\end{array}\end{array}$} \\
\hline \multicolumn{5}{|c|}{ [X] All three criteria have been satisfied. The Item meets the definition of commercial grade. } \\
\hline \multicolumn{5}{|c|}{ M 1. } \\
\hline \multirow[t]{5}{*}{$\mathbf{x}$} & \multicolumn{4}{|c|}{ Item is being purchased from a non-ESL manufacturer supplier as CG to be used in a Safety Class application. } \\
\hline & \multicolumn{4}{|c|}{ Item is being purchased from a non-ESL manufacturer supplier as CG to be used in a Safety Significant application. } \\
\hline & \multicolumn{4}{|c|}{ Item was purchased from a non-ESL manufacturer supplier as CG to be used in a Safety Class application. } \\
\hline & \multicolumn{4}{|c|}{ Item was purchased from a non-ESL manufacturer supplier as CG to be used in a Safety Significant application. } \\
\hline & & & tion) & \\
\hline
\end{tabular}




\begin{tabular}{|l|l|}
\hline Commercial Grade Item Upgrade Dedication Form & SNF-3890, Rev. 3 \\
\hline $\begin{array}{l}\text { ECN No. NA CGI No. CGI-SNF-D-46-1-P4-015 } \\
\text { Title: Worcester Solenoid-Actuated Gas-Operated MCO Isolation Valves }\end{array}$ & Page 2 of 10 \\
\hline
\end{tabular}

\section{Socton T Teline Etecis Eveluation}

\section{A. Part/Component Safety Function:}

1. Maintain an intact pressure boundary/confinement.

2. Isolate the $\mathrm{MCO}$ in the event of loss of vacuum to reduce air in-leakage or loss of $\mathrm{He}$, prevent an $\mathrm{H}_{2}$ explosion.

3. Maintain critical function before and after seismic event.

B. Part/Component Functional Mode:

Safety Function\#1: [ ] Active [X] Passive

Safety Function \#2: [X] Active [ ] Passive

Safety Function \#3: [ $]$ Active [X] Passive
Active - Mechanical or Electrical change of state is required to occur for the component to perform its safely function
Passive - Change of state is not required for the component to perform its safety function

C. Host Component Safety Function (if applicable): N/A

1.

D. Failure Mode(s) and the effects on component or system safety function (see Worksheet 1):

1. Structural or mechanical failure of these valves could cause loss of $\mathrm{MCO}$ isolation functions and resultant rapid bleed off of the Helium to the $\mathrm{MCO}$, air in-leakage to the $\mathrm{MCO}$, or inadvertent $\mathrm{MCO}$ water drainage.

2. Electrical fault in solenoid. Valve fails closed.

3. Loss of air pressure to actuator. Valve fails closed.

4. Loss of control signal to solenoid. Valve fails closed.

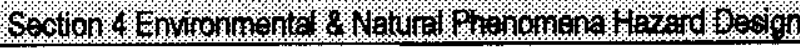

Environmental Qualification Required:

Yes [ ]

No [X] Environmental Condition $\mathrm{B}$
If yes: Environmental Qualification Requirements

Limiting Environmental Conditions:

Required Safety Functions:

Qualification Period:

If yes: NPH Design Requirements

Performance Category: PC-3

NPH Design Req'ts.: Seismic Condition A

Required Safety Functions: Boundary/Confinement, Isolation, Prevent $\mathrm{H}_{2}$ Explosion

\section{SNF 5303}

Yes $[\mathbf{X}]$

No 11

HNF-PRO-97

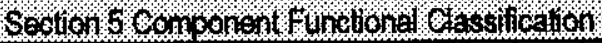

\begin{tabular}{|l|l|l|l|l|l}
$\mathbf{X}$ & Safety Class (SC) & & General Service (GS) & & Safety Significant (SS) \\
\hline
\end{tabular}

If part/component classification is different from host component/system, document basis. N/A

\section{Soctions 6 and $7 /$ Resencod}

\section{Secton 8 Reterunoes (for Munctional G(assitication)}

National Codes/Standards: ASME B31.3

Safety Analysis Report (SAR); HNF. 3553, Annex B

Drawings: H-1-82161, HNF-SD-SNF-SEL-002

Vendor Manual/Manufacturer/Supplier Information: Worcester PB 451-22, PB 302-26, PB 303-1 


\begin{tabular}{|l|l|}
\hline Commercial Grade Item Upgrade Dedication Form & SNF-3890, Rev. 3 \\
\hline $\begin{array}{l}\text { ECN No. NA CGI No. CGI-SNF-D-46-1-P4-015 } \\
\text { Title: Worcester Solenoid-Actuated Gas-Operated MCO Isolation Valves }\end{array}$ & Page 3 of 10 \\
\hline
\end{tabular}

\begin{tabular}{|c|c|c|c|c|}
\hline \multicolumn{5}{|c|}{ 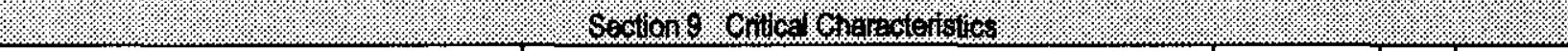 } \\
\hline Critical Characteristics & Acceptance Criteria/Tolerances & $\begin{array}{l}\text { Acceptance } \\
\text { Method }\end{array}$ & ID & Function \\
\hline \multicolumn{5}{|c|}{ 1. Item Identification Critical Characteristics (necessary for reasonable assurance that the Item delivered is the Item specified) } \\
\hline Nameplate - Manufacturer & Worcester Controls & 1, IN & $\mathbf{x}$ & \\
\hline $\begin{array}{l}\text { Valve-Component Number- } \\
\text { Procurement and/or Model Number }\end{array}$ & $\begin{array}{l}\text { 1" E 5966RTBW4 (Per Procurement Package W- } \\
\text { 441-P4, Rev. 3, Section H, Design Data Sheet) }\end{array}$ & 1, IN & $\mathbf{x}$ & \\
\hline $\begin{array}{l}\text { Actuator-Component Number- } \\
\text { Procurement and/or Model Number }\end{array}$ & $\begin{array}{l}\text { 151939SWM2120PBC (Per Procurement Package } \\
\text { W-441-P4, Rev 2, Section H, Design Data Sheet) }\end{array}$ & $1, \mathbb{I N}$ & $\mathbf{x}$ & \\
\hline (Includes sov) & $\begin{array}{l}\text { (Either Model Number } 1519395 W M 2120 \mathrm{PBC} \text { or } \\
151395 W M 2120 \mathrm{PBC} \text { is acceptable because valve } \\
\text { failure position will be verified for } 100 \% \text { of items } \\
\text { as a Critical Characteristic.) }\end{array}$ & & & \\
\hline $\begin{array}{l}\text { Nameplate Data of Actuator } \\
\text { (Includes SOV) }\end{array}$ & $\begin{array}{l}\text { Per Vendor Manual. To Include "R6" (Upper Right } \\
\text { Corner) }\end{array}$ & 1, IN & $\mathrm{x}$ & \\
\hline \multicolumn{5}{|c|}{ 2. Physical Critical Characteristics (for reasonable assurance that the Item delivered is the Item specified) } \\
\hline Valve Body Material & Stainless Steel (Note 4) & $1, \mathrm{IN} ; 1, \mathrm{~T}$ & $\mathbf{x}$ & \\
\hline Configuration/Mounting & $\begin{array}{l}\text { Integral ActuatorNalve Assembly. Transverse } \\
\text { Actuator Mounting. Black Recessed Override } \\
\text { Button. }\end{array}$ & $1, \mathrm{IN}$ & $x$ & \\
\hline Valve Seat & Reinforced TFE cavity filled seat & 1, IN & $\mathbf{x}$ & \\
\hline \multicolumn{5}{|c|}{ 3. Performance Critical Characteristics (for reasonable assurance that the Item will perform its intended safely function(s)) } \\
\hline GOV Pressure Boundary & $\begin{array}{l}\text { Pressure Test At Nominal } 165 \text { psig (Zero } \\
\text { Leakage) Note } 3\end{array}$ & $1, T$ & & $\mathbf{X}$ \\
\hline Internal Pressure & $\begin{array}{l}\text { Withstands nominal } 150 \text { psig and } 29 " \mathrm{Hg} \text { Vacuum } \\
\text { (Zero Leakage) }\end{array}$ & $1, T$ & & $\mathrm{x}$ \\
\hline GoV Seat Leakage & $\begin{array}{l}\text { Pressurize the upstream side of the valve seat to } \\
165 \text { psig }(110 \%) \text { and reduce to } 150 \text { psig }(110 \%) \text {, } \\
\text { soaking for } 10 \text { min. at } 150 \text { psig, then check for } \\
\text { obvious leaks. Apply bubble leak solution on the } \\
\text { valve seat to find leaks. Proceed to lower the } \\
\text { pressure to } 15 \text { psig for the Sensitive Leak Test. } \\
\text { Apply solution to valve seat area after minimum } \\
15 \text { minutes soak time at nominal } 15 \text { psig. } \\
\text { Acc. Criteria: No Leakage-No Bubbles. Note } 5\end{array}$ & $1, T$ & & $\mathbf{x}$ \\
\hline GOV Fail Safe Position & $\begin{array}{l}\text { Valve Fails Closed on Loss of Air Pressure or } \\
\text { Electrical Power to the Solenoid. Stroke Time } \\
\text { Less Than } 2 \text { Seconds. }\end{array}$ & $1, T$ & & $\mathbf{x}$ \\
\hline Environmental & Note 1 & & & \\
\hline Seismic Condition A & Note 2 & $1, T$ & & $x$ \\
\hline
\end{tabular}




\begin{tabular}{|l|l|}
\hline Commercial Grade Item Upgrade Dedication Form & SNF-3890, Rev. 3 \\
\hline $\begin{array}{l}\text { ECN No. NA } \\
\text { Title: Worcester Solenoid-Actuated Gas-Operated MCO Isolation Valves }\end{array}$ & Page 4 of 10 \\
\hline
\end{tabular}

4. Notes and Legend:

1. These valves have coro-lube (nickel-acetate), acetal resin, and NEMA Enclosed Solenoids, these materials are not subject to degradation at $40^{\circ} \mathrm{F}$ and $60 \%$ RH or $115 \circ$ and $22 \% \mathrm{RH}$ and are suitable for condition B Application.

2. Maintain critical function before and after seismic event. W-441-P4, Rev. 3, Appendix $L$, pages $L-2 \&$ L-4, provide a seismic testing plan for these components at a (TBD) seismic spectra. Equipment that has been shakertable tested should not be installed in a plant (Ref. IEEE Standard 344-1984, Section 7). Consequently, the seismic test constitutes a destructive test. The industry sampling practice for destructive test is to test only one item.

3. Pressure test at $110 \%$ of design accident condition pressure of $150 \mathrm{psig}$.

4. Material verification acceptance method may be by either inspection or test.

5. $15 \mathrm{psig}=15 \mathrm{psig}$ or $25 \%$ of $150 \mathrm{psig}=37.5$ whichever is less (ASME V, Article 10, $T-1044$ and $B 31.1-1993,345.8(a))$

Rev. 2: Rev'd all pages - new forms; rev'd Internal Pressure Acc. Criteria to "Withstands nominal 150 psig and 29" $\mathrm{Hg}$ Vacuum", GOV Seat Leakage Acc. Criteria - rev'd all, GOV Fail Safe Position rev'd Stroke Time to "Less Than 2 Seconds", Deleted CC: Insulation Resistance, Solenoid Inrush Current, Solenoid Holding Current, and Current Carrying Capability of Contacts

Rev. 3: Added note that either actuator Model Number is acceptable; revised valve failure position sampling size to $100 \%$; Revised stroke time to be a separate item in Section 4, By Special Test and Section 5.

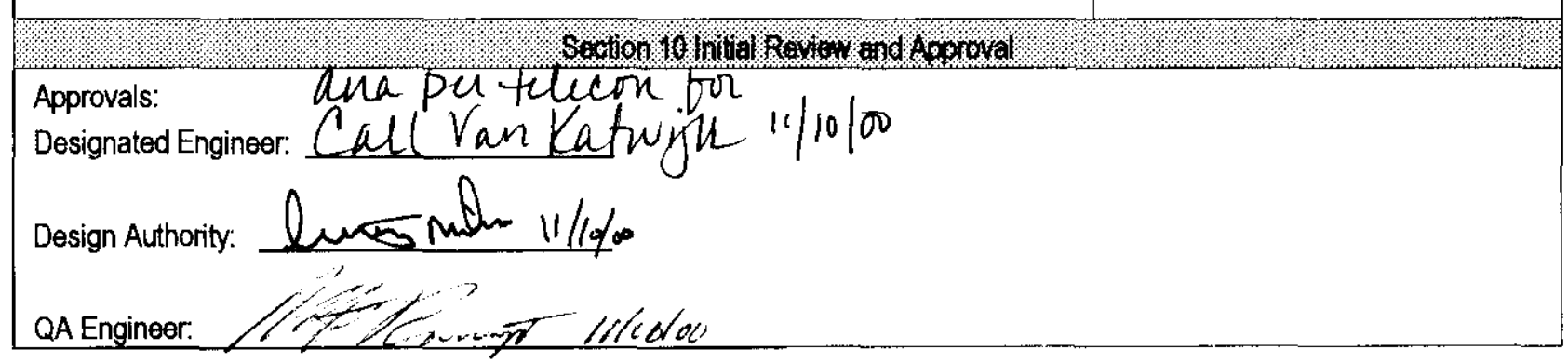

Acceptance Method:

1. Special Test and inspection

1, IN for inspection

1,T for Test

2. Commercial Grade Survey

3. Source Verification

4. Vendor/tem History 


\begin{tabular}{|l|l|}
\hline Commercial Grade Item Upgrade Dedication Form & SNF-3890, Rev. 3 \\
\hline $\begin{array}{l}\text { ECN No. NA CGI No. CGI-SNF-D-46-1-P4-015 } \\
\text { Titte: Worcester Solenoid-Actuated Gas-Operated MCO Isolation Valves }\end{array}$ & Page 5 of 10 \\
\hline
\end{tabular}

WORKSHEET 1

\section{DETERMINATION OF FAILURE MECHANISMS}

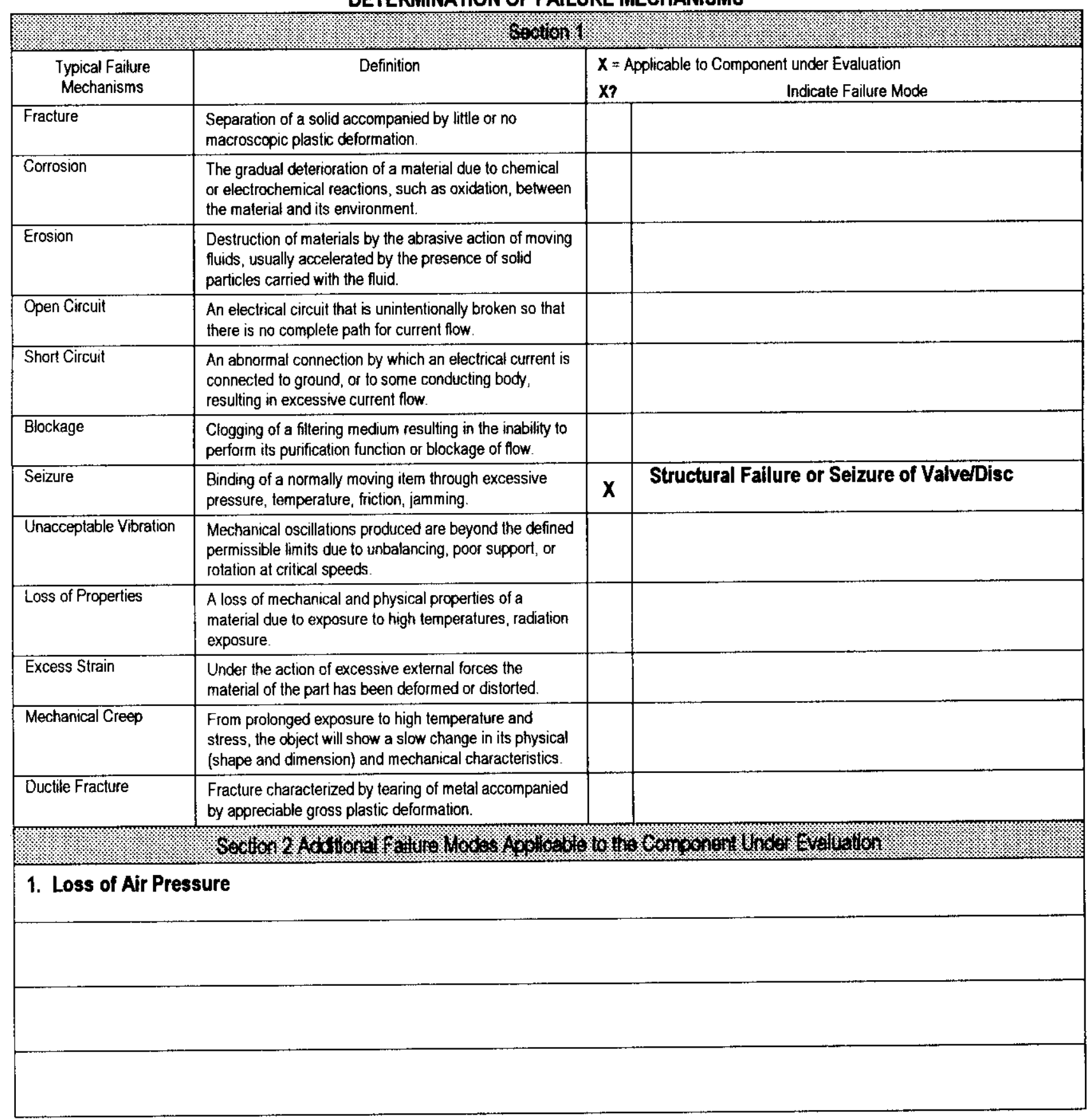




\begin{tabular}{|l|l|}
\hline Commercial Grade Item Upgrade Dedication Form & SNF-3890, Rev. 3 \\
\hline $\begin{array}{l}\text { ECN No. NA CGI No. CGI-SNF-D-46-1-P4-015 } \\
\text { Title: Worcester Solenoid-Actuated Gas-Operated MCO lsolation Valves }\end{array}$ & Page 6 of 10 \\
\hline
\end{tabular}

Checklist 1 - Acceptance Method 1 - Special Test/nspection Verification

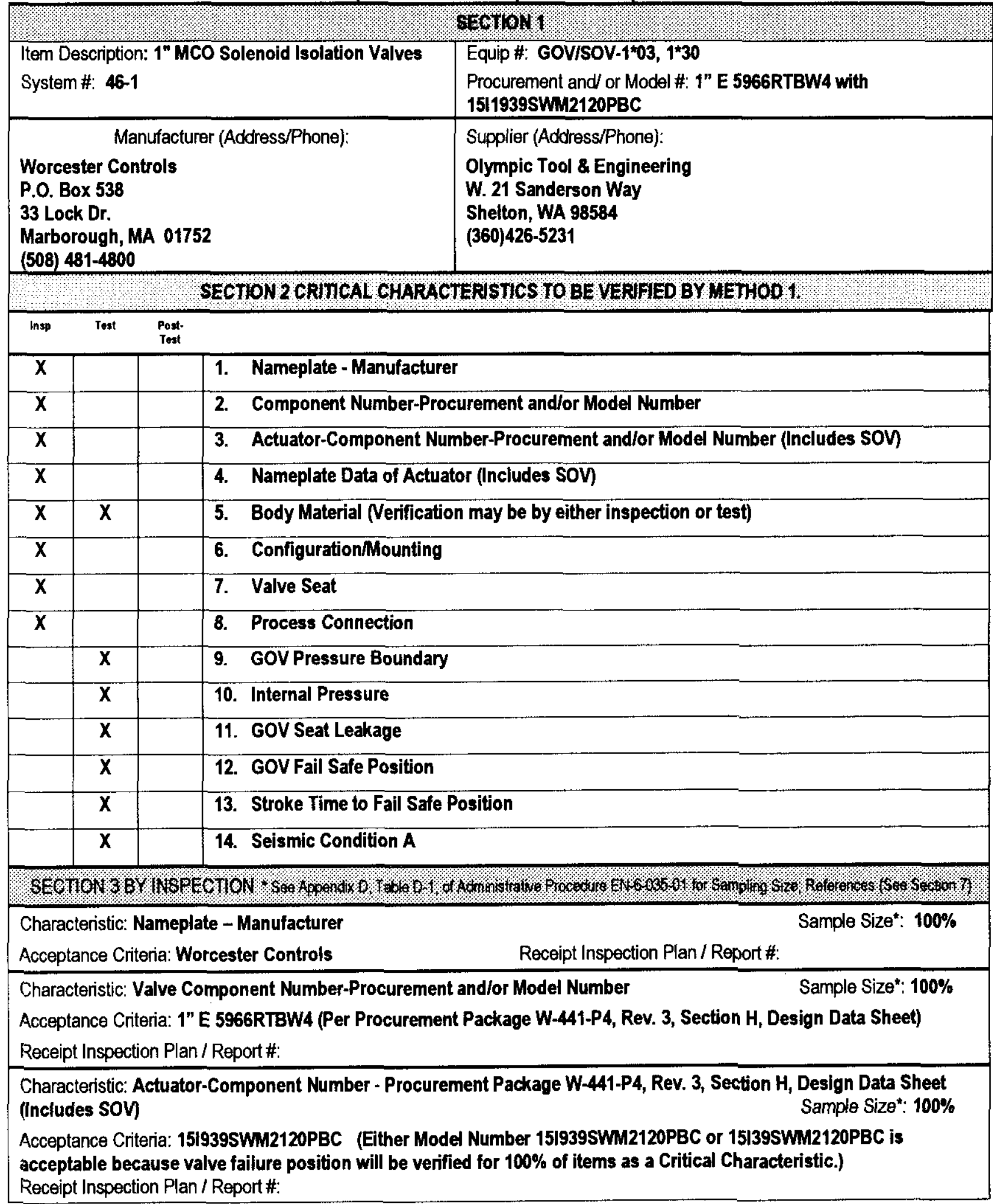




\begin{tabular}{|l|l|}
\hline Commercial Grade Item Upgrade Dedication Form & SNF-3890, Rev. 3 \\
\hline $\begin{array}{l}\text { ECN No. NA CGI No. CGI-SNF-D-46-1-P4-015 } \\
\text { Titte: Worcester Solenoid-Actuated Gas-Operated MCO isolation Valves }\end{array}$ & Page 7 of 10 \\
\hline
\end{tabular}

Characteristic Nameplate Data of Actuator (Includes SOV)

Sample Size*: $100 \%$

Acceptance Criteria:Per Vendor Manual. To Include "R6" (Upper Right Corner). Receipt Insp. Plan / Report\#:

Characteristic: Valve Seat
Acceptance Criteria: Reinforced TFE cavity filled seat $\quad$ Receipt Inspection Plan / Report\#:

Characteristic: Configuration/Mounting Sample Size*: 100\%

Acceptance Criteria: Integral ActuatorNalve Assy. Transverse Actuator Mounting. Black Recessed Override Button.

Receipt Inspection Plan / Report \#:

Characteristic: Valve Body Material

Acceptance Criteria: Stainless Steel

Receipt Inspection Plan / Report\#:

Sample Size $: 100 \%$

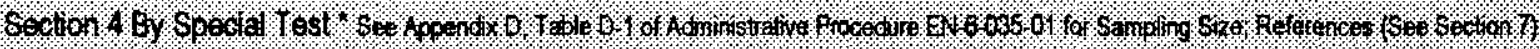

Characteristic for Test: GOV Pressure Boundary

Samp Size: : [X]Normal[ ]Reduced[ JTightened

Acceptance Criteria: Pressure Test at nominal 165 psig for $>10$ minutes; Reduce pressure to $100 \%$, perform snoop test

(No Leakage-No Bubbles)

Actual Test Value:

Test Plan and Report \#:

Characteristic for Test: Internal Pressure

Samp Size : [X]Normal[ ]Reduced[ ]Tightened

Acceptance Criteria: Withstands nominal $150 \mathrm{psig}$ and 29" Hg Vacuum (Zero Leakage)

Actual Test Value:

Test Plan and Report \#:

Characteristic for Test: GOV Seat Leakage

Samp Size*: [X]Normal[ ]Reduced[ ]Tightened

Acceptance Criteria: Pressurize the upstream side of the valve seat to $165 \mathrm{psig}(110 \%)$ and reduce to $150 \mathrm{psig}(110 \%)$, soaking for $10 \mathrm{~min}$. at $150 \mathrm{psig}$, then check for obvious leaks. Apply bubble leak solution on the valve seat to find leaks. Proceed to lower the pressure to $15 \mathrm{psig}$ for the Sensitive Leak Test. Apply solution to valve seat area after minimum 15 minutes soak time at nominal 15 psig.

Acc. Criteria: No Leakage-No Bubbles.

Actual Test Value:

Test Plan and Report \#:

Characteristic for Test: GOV Fail Safe Position

Samp Size*: $100 \%$

Acceptance Criteria: Valve Fails Closed on Loss of Air Pressure or Electrical Power to the Solenoid.

Actual Test Value:

Test Plan and Report \#:

Characteristic for Test: Stroke Time to Fail Safe Position

Samp Size*: : : [X]Normal[ ]Reduced[ ]Tightened

Acceptance Criteria: Stroke Time <2 Sec.

Actual Test Value:

Test Plan and Report \#:

Characteristic for Test: Seismic Condition A

Samp Size: Destructively Test Only One ltem

Acceptance Criteria: Maintain Critical Function Before and After Seismic Event

Actual Test Value:

Test Plan and Report \#:

**If Supplier/Manufacturer or Other, Refer to CGI Checklist-2 for Support Information 


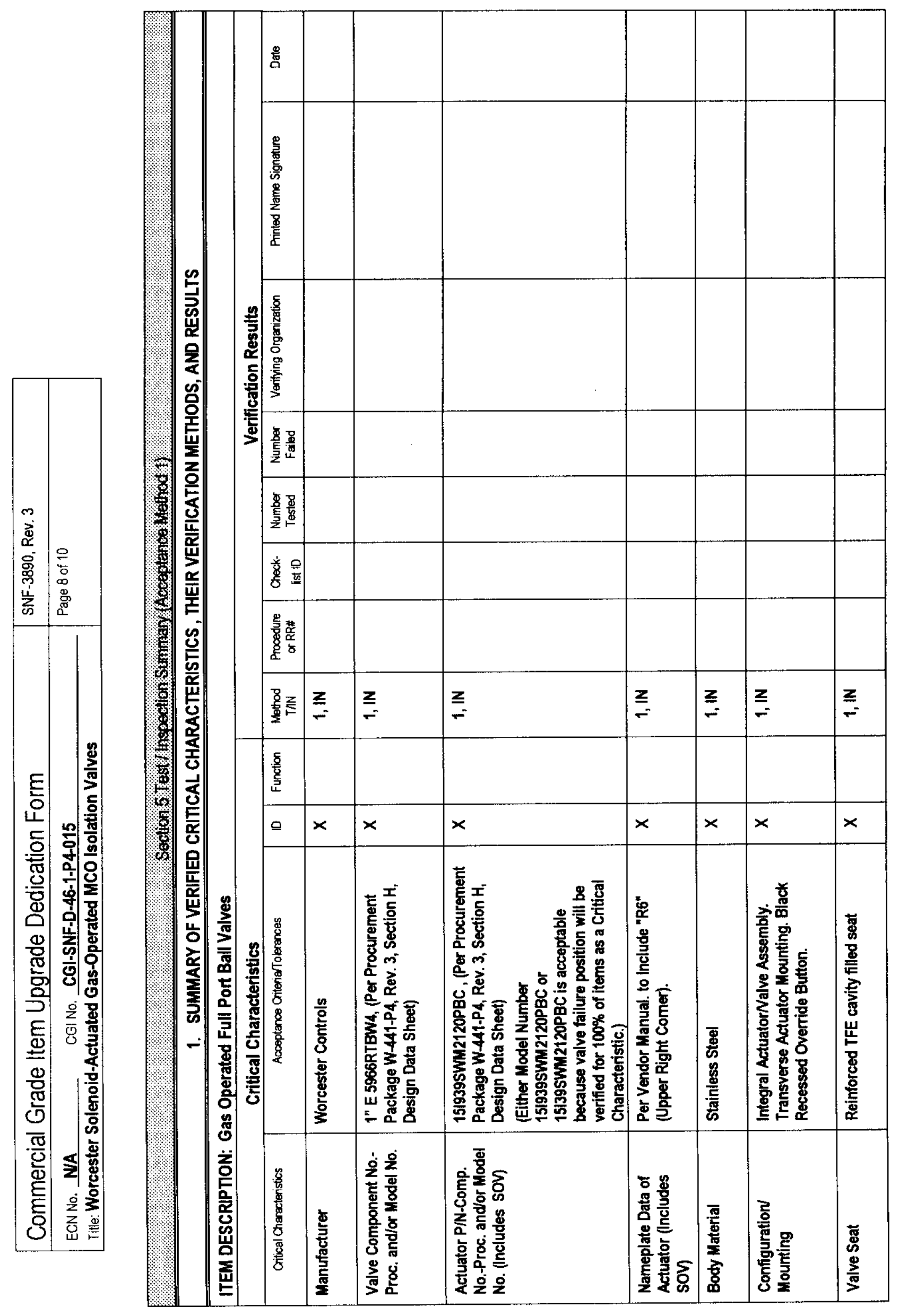




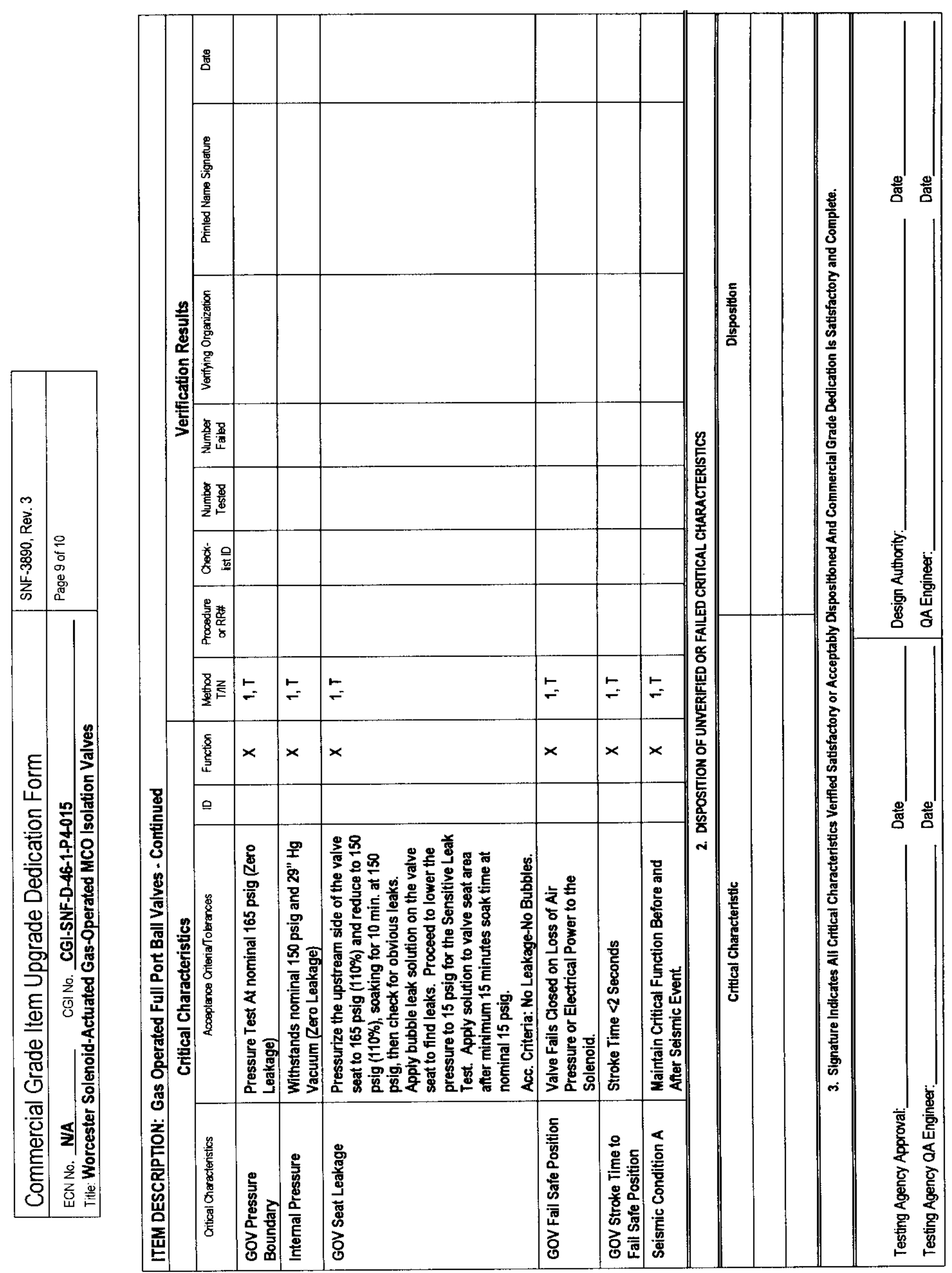




\begin{tabular}{|l|l|}
\hline Commercial Grade Item Upgrade Dedication Form & SNF-3890, Rev. 3 \\
\hline ECN No. NAA CGI No. CGI-SNF-D-46-1-P4-015 & Page 10 of 10 \\
Title: Worcester Solenoid-Actuated Gas-Operated MCO Isolation Valves & \\
\hline
\end{tabular}

\begin{tabular}{|c|c|c|c|c|}
\hline \multicolumn{4}{|c|}{ 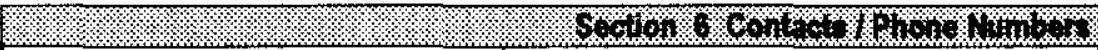 } & \% \\
\hline & Title & \multicolumn{2}{|c|}{ Name } & Phone \\
\hline \multicolumn{5}{|c|}{ Design Authority } \\
\hline \multicolumn{5}{|c|}{ QA } \\
\hline \multicolumn{5}{|c|}{ QC } \\
\hline \multicolumn{5}{|c|}{ Cog - Engineer } \\
\hline \multicolumn{2}{|c|}{ CGI Engineer } & \multicolumn{2}{|c|}{ Larry Price } & $372-8770$ \\
\hline \multicolumn{5}{|c|}{ Procurement Engineer } \\
\hline \multicolumn{5}{|c|}{ Other } \\
\hline \multicolumn{5}{|c|}{ 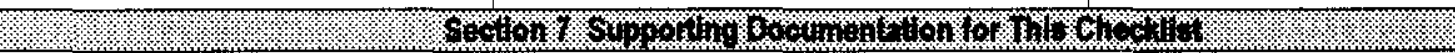 } \\
\hline \multicolumn{3}{|c|}{ Initial Procurement Documents } & \multicolumn{2}{|c|}{ For Critical Characteristics } \\
\hline \multicolumn{5}{|c|}{ Drawings: } \\
\hline \multicolumn{5}{|c|}{ Manuals (specify type \& number): } \\
\hline \multicolumn{5}{|c|}{ Design Calculations } \\
\hline \multicolumn{5}{|c|}{ Installation Instructions } \\
\hline \multicolumn{5}{|c|}{ Operation Instructions } \\
\hline \multicolumn{5}{|c|}{ Calibration Instructions } \\
\hline \multicolumn{5}{|c|}{ Manufacturer's Recommended Spare Parts List } \\
\hline \multicolumn{3}{|c|}{\begin{tabular}{l|l}
$X$ & Other: Vendor Specifications: Worcester PB 451-22, PB \\
302-26, PB 303-1
\end{tabular}} & \multicolumn{2}{|l|}{ All } \\
\hline \multicolumn{5}{|c|}{ Procurement Documents } \\
\hline \multicolumn{5}{|c|}{ Certificate of Conformance/Compliance } \\
\hline \multicolumn{5}{|c|}{ Seismic Qualification Certificate } \\
\hline \multicolumn{5}{|c|}{ Environmental Qualification Certificate } \\
\hline \multicolumn{5}{|c|}{ Test Report (s): } \\
\hline \multicolumn{5}{|c|}{ Inspection Report (s): } \\
\hline \multicolumn{5}{|c|}{ CMTRs for ASME Pressure Retaining Materials } \\
\hline \multicolumn{5}{|c|}{ Valve Seat Leakage Report } \\
\hline \multicolumn{5}{|c|}{ Weld Records } \\
\hline \multicolumn{3}{|c|}{ Material Traceability Record } & & \\
\hline & Other: & & & \\
\hline
\end{tabular}

